\title{
Do business process reengineering projects payoff? Evidence from the United States
}

\author{
Yasin Ozcelik \\ Fairfield University, yozcelik@fairfield.edu
}

Follow this and additional works at: https://digitalcommons.fairfield.edu/business-facultypubs NOTICE: this is the author's version of a work that was accepted for publication in International Journal of Project Management. Changes resulting from the publishing process, such as peer review, editing, corrections, structural formatting, and other quality control mechanisms may not be reflected in this document. Changes may have been made to this work since it was submitted for publication. A definitive version was subsequently published in International Journal of Project Management [28, 1, 2010] DOI: 10.1016/j.ijproman.2009.03.004

\section{Peer Reviewed}

\section{Repository Citation}

Ozcelik, Yasin, "Do business process reengineering projects payoff? Evidence from the United States" (2010). Business Faculty Publications. 17.

https://digitalcommons.fairfield.edu/business-facultypubs/17

\section{Published Citation}

Ozcelik, Yasin. 2010. Do business process reengineering projects payoff? Evidence from the United States. International Journal of Project Management 28 (1), 7-13.

This item has been accepted for inclusion in DigitalCommons@Fairfield by an authorized administrator of DigitalCommons@Fairfield. It is brought to you by DigitalCommons@Fairfield with permission from the rightsholder(s) and is protected by copyright and/or related rights. You are free to use this item in any way that is permitted by the copyright and related rights legislation that applies to your use. For other uses, you need to obtain permission from the rights-holder(s) directly, unless additional rights are indicated by a Creative Commons license in the record and/or on the work itself. For more information, please contact digitalcommons@fairfield.edu. 


\title{
Do Business Process Reengineering Projects Payoff? Evidence from the United States
}

\author{
Revised - February 2009
}

\begin{abstract}
This paper examines whether implementation of Business Process Reengineering (BPR) projects improve firm performance by analyzing a comprehensive data set on large firms in the United States. The performance measures utilized in the paper are labor productivity, return on assets, and return on equity. We show that firm performance increases after the BPR projects are finalized, while it remains unaffected during execution. We also find that functionally focused BPR projects on average contribute more to performance than those with a broader cross-functional scope. This may be an indication that potential failure risk of BPR projects may increase beyond a certain level of scope.
\end{abstract}

Keywords: Business process reengineering; value and benefit; statistical analysis 


\section{Introduction}

Business Process Reengineering (BPR) is defined as a radical redesign of processes in order to gain significant improvements in cost, quality, and service. Firms have been reengineering various business functions for years, ranging from customer relationship management to order fulfilment, and from assembly lines to logistics. Anecdotal evidence suggests that many organizations gained benefits from BPR projects [1]. For instance, the CIGNA Corporation successfully completed a number of BPR projects and realized savings of $\$ 100$ million by improving its customer service and reducing operating expenses [2]. Similarly, reengineering the accounts payable process at the Ford Motor Company increased the speed of payments and improved company relations with suppliers [3]. Arguably, some BPR projects fail to meet expectations. A survey conducted by the Arthur D. Little consulting firm found that $85 \%$ of executives surveyed were not satisfied with the outcome of their BPR projects [4]. Moreover, a series of studies in the early 1990s found that nearly $70 \%$ of BPR initiatives had actually failed [5] or delivered less than they had promised [6]. Such poor outcomes may be attributed to several factors, including (i) expecting too much too soon [3], (ii) undertaking projects without a comprehensive cost-benefit analysis, (iii) lack of expertise on redesigning a set of related activities [7], and (iv) lack of partnership between internal Information Technology (IT) department and other parts of firms [8].

BPR projects, by their nature, entail major changes in business processes that may lead to organizational instability and failure. Therefore, it is reasonable to expect BPR projects to have a significant and measurable effect on firm performance. In this paper, we empirically investigate the performance effects of BPR projects both during and after the implementation periods using a new annual data set covering the period between 1984 and 
2004. We utilize labor productivity, return on assets, and return on equity as firm-level performance variables. We use a panel-data regression model in order to take into account the cross-sectional and time-series nature of the data. We show that performance variables of firms remain unaffected during the implementation period of the BPR projects, which generally creates an initial turmoil in firm operations. The firm performance, however, significantly increases after the BPR projects are successfully completed. We also find that functionally focused BPR projects contribute more to performance than those with a broader cross-functional scope, suggesting that failure risk of BPR projects may increase beyond a certain scope.

The paper is organized as follows. In the next section, we briefly survey previous studies on the topic, and then present our hypotheses in Section 3. We describe our data in Section 4 and regression variables in Section 5. We then describe our empirical methods in Section 6. Finally, we provide the regression results in Section 7 and conclude in Section 8.

\section{Literature Review}

BPR was first described by Davenport and Short [9] and Hammer [10]. Despite the growing popularity of BPR in 1990s, different management consultants used the term as a way to promote their proprietary methods, which led to confusion and disagreements [11]. Responding to the claims made for BPR and the resulting confusion, the academic community criticized BPR for having no sound theoretical basis [12]. Deakins and Makgill [13] argues that the original literature on BPR was essentially anecdotal, lacking rigorous research to support its assertions. More recent literature suggests that the first generation of BPR, which suggests radical changes in business processes, is evolving in to a modest process management, which is softened by the lessons learned from successes and failures in 
the course of implementations. The contemporary definition of BPR, therefore, encompasses a continuum of approaches to process transformation that may include both radical and incremental improvements, depending on the nature of the problem. In fact, many studies have been published in the literature in order to explain and promote this new approach to BPR, including Davenport et al. [14], Hammer [15], Hammer [16], Becker et al. [17], El Sawy [18], Grover and Kettinger [6], Kalakota and Robinson [19], Silver [20], and Smith and Fingar [21]. Nevertheless, even the recent literature is rife with anecdotal evidence and short on empirical evidence of performance impacts of BPR projects. This indicates that there is still a need to better measure BPR implementations through objective measures, and to relate them to organizational performance in the context of other variables that may also affect performance, which is the main focus of this paper.

The number of studies on the impact of BPR projects on firm performance is small but growing. Most studies collectively suggest that there are substantial benefits for firms that successfully implement the structural changes associated with BPR projects [22, 23]. Hunter et al. [24] and Murnane et al. [25] confirm this claim by analyzing data from the banking industry per se. Devaraj and Kohli [26] show that investments in IT can contribute to a higher level of revenue if they are supported by BPR initiatives. By studying the effect of three related innovations (IT, workplace reorganization, and new products and services) on demand for skilled labor, Bresnahan et al. [27] find that the demand for skilled labor is complementary with all the three innovations. Finally, Bertschek and Kaiser [28] find that workplace reorganization induces an increase in labor productivity that may be attributable to complementarities between IT and workplace reorganization. 


\section{Hypotheses}

BPR projects involve large investments in physical as well as human capital. The monetary costs of a BPR project include purchasing new equipment, hiring new personnel, and training employees to handle new roles. Indeed, organizations implementing BPR projects may need to increase their training budgets by 30 to 50 percent [29]. BPR projects may also have nonpecuniary costs due to problems encountered during implementation [30]. Such problems include (i) communications barriers between functional areas [31], (ii) lack of communication between top-level managers [32] as well as between BPR teams and other employees [33], (iii) resistance from employees [34], (iv) management reluctance to commit resources to BPR projects while expecting quick results [35], and (v) failing to address employee habits during implementation [36]. All of these factors suggest the following hypothesis:

Hypothesis 1. Firms experience a drop in performance during BPR project implementation.

Once BPR projects are finalized and implementation risks are resolved, employees are likely to become more comfortable with the new process design, and hence firms may be able to operate more efficiently. Thus, we expect firm performance to surpass its previous levels after the implementation, which leads to our second hypothesis:

Hypothesis 2. Firm performance improves after the completion of BPR projects.

A third issue of interest is the effect of project scope on firm performance. The scope of BPR projects vary; some projects focus on a single business function, such as order fulfilment or accounts payable, while others may be directed towards multiple functions. The scope of BPR projects may potentially affect the level of impact on firm performance. However, studies in the literature are far from providing consistent evidence on the direction of the impact. For example, Berry et al. [37] find that BPR projects with a large scope make the 
highest possible impact on firm performance. On the other hand, Dean [38] finds that the application of BPR across the entire firm may not produce as much benefit as a functionallyoriented project, such as switching to Just-in-Time (JIT) production system. In order to better investigate this issue empirically, we incorporate a scope variable into our analysis and suggest the following hypothesis:

Hypothesis 3. The effect of BPR projects on firm performance increases with project scope.

\section{Description of Data}

Our data covers BPR projects conducted by large U.S firms between 1985 and 2000. In order to avoid selection bias, we included in our sample all of the firms appearing in the 1998 edition of the Fortune 1000 list, regardless of whether they have implemented a BPR project. We used the ABI/INFORM and Lexis/Nexis online news resources to obtain press announcements for BPR projects, as well as the COMPUSTAT to extract our data. All of the monetary values in our data were inflation-adjusted by using the Consumer Price Index (CPI) values of the Federal Reserve Bank of Minneapolis, with the base year being chained at 1982-1984. We eliminated some of the firms due to missing data, reducing our sample size to 832 firms with a time span between 1984 and 2004. Of these firms, 93 have implemented a BPR project. We classified the BPR projects in to two groups with respect to project scope. Projects that likely affect a single business unit were classified as being functionally focused. Examples include reengineering of records management, sales force, and labor scheduling. Projects that potentially affect several departments were considered to have a cross-functional focus. Examples of such projects include restructuring and strategic rethinking of business for cost cutting or revenue growth purposes. Overall, 56 of the 93 projects in our data set were cross-functional and 37 were functionally oriented. 


\section{Description of Variables}

\subsection{Dependent and Independent Variables}

We utilize labor productivity, Return on Assets (ROA), and Return on Equity (ROE) as dependent variables to measure firm performance from several dimensions. Table 1 below outlines the construction of these measures.

\section{[Insert Table 1 here]}

Our key independent variables are the following. The implementation period is distinguished with a dummy that takes a value of one for all years during which a firm implements a BPR project, and zero otherwise. The post-BPR period is designated with another dummy that takes a value of one during all years after the implementation, and zero otherwise. These dummies allow us to take a longitudinal approach and are used for testing Hypotheses 1 and 2. Regarding Hypothesis 3, each of the above dummies is separated into two dummies, one for cross-functional BPR projects and the other for projects with a functional focus. For example, the dummy for the implementation period of cross-functional BPR projects is one for all years during which a firm implements the associated BPR project, and zero otherwise.

\subsection{Control Variables}

Our model includes four firm-level and two industry-level control variables. Past empirical studies have identified these controls as key determinants of firm performance $[39,40]$.

5.2.1. Firm-level Controls: Our firm-level control variables are firm size, total IT budget, advertising expenditure, and market share. First, we use the natural logarithm of the number of employees as a proxy for firm size, as is standard in the literature. Second, in order to distinguish the effect of BPR projects on performance across firms with varying degrees of technical capability, we utilize the total IT budget as another firm-level control variable. 
Third, there is ample evidence in the literature supporting a positive relationship between advertising expenditure and firm performance [41, 42, 43]. Finally, market share is included as a control variable because both the efficiency theory $[44,45]$ and the market power theory [46, 47] provide evidence for a relationship between market share and firm performance. Market share can also serve as a proxy for other firm-specific assets not specifically captured in our study, such as managerial skills [48, 49].

5.2.2. Industry-level Controls: The structure of an industry impacts the performance of firms within the industry [50]. We, therefore, utilize two variables frequently used in the literature to account for variation in firm performance due to idiosyncratic characteristics of different industries at the 2-digit SIC level: industry concentration and industry capital intensity. Consistent with the literature, industry concentration in our study is proxied by the four-firm concentration ratio, which is the total market share of the four largest firms in an industry. Industry capital intensity is included in the analysis to capture potential effects of entry barriers on firm performance. It is calculated as the sum of all capital expenditures divided by the sum of all sales in an industry.

5.2.3. Time Controls: We use separate dummy variables for each year to capture economywide shocks that may affect firm performance. The use of such dummies also helps us remove possible correlation between macroeconomic trends and firms' performances during the sample period.

\section{Empirical Methods}

We perform a panel data analysis to test our hypotheses as it accounts for both the time series and cross-sectional nature of our data. Panel data models have two estimation methods: fixed effects and random effects. The advantage of fixed effects estimation over random effects is 
that the former method allows the unobserved effect to correlate with the observed explanatory variables. The disadvantage is that fixed effects estimation produces less efficient estimators than random effects estimation can provide. The generally accepted way of choosing between fixed and random effects is running a Hausman test, and our regression results unanimously suggest using fixed effects estimation for all the regressions.

We use the logarithm of the numerator of each performance measure as a dependent variable, and the logarithm of its denominator as a control variable. This formulation relies on a property of the $\log$ arithm function, $\log (\mathrm{x} / \mathrm{y})=\log (\mathrm{x})-\log (\mathrm{y})$. Such a specification has been used in past research as it provides flexibility in the relationship between the numerator and the denominator, while still retaining the interpretation as a performance measure [51]. Thus, the general form of the regression models used for testing Hypotheses 1 and 2 is:

$$
\begin{aligned}
\log \left({\text { performance measure numerator })_{i t}=}\right. & \text { intercept }_{i}+\log (\text { performance measure denominator })_{i t} \\
& + \text { implementation }_{i t}+\text { post-implementation }_{i t} \\
& +{\text { firm } \text { controls }_{i t}+\text { industry controls }_{i t}} \\
& + \text { year dummies } \\
& +\varepsilon_{i t}
\end{aligned}
$$

The implementation variable above is derived by interacting the dummy for the implementation period with firm size. This is equivalent to specifying that both the costs and benefits of BPR projects during the implementation period are proportional to firm size. We believe this is a more realistic specification than simply assuming identical costs and benefits across all firms, which would be the case if we were to include in the analysis the implementation period dummy per se. By the same token, the post-implementation variable is derived by interacting the dummy for the post-implementation period with firm size.

As for testing Hypothesis 3, we segment the implementation and post-implementation variables in to two types: functionally focused and cross-functional. Again, these variables 
are derived by interacting the associated dummies with firm size. Hence, the formulation of the fixed effects panel data models when investigating the effect of project scope becomes:

$$
\begin{aligned}
& \log (\text { performance measure numerator })_{i t}=\text { intercept }_{i}+\log (\text { performance measure denominator })_{i t} \\
& + \text { functional implementation }_{i t}+\text { functional post-implementation }_{i t} \\
& + \text { cross-functional implementation }_{i t}+\text { cross-functional post-implementation }_{i t}
\end{aligned}
$$

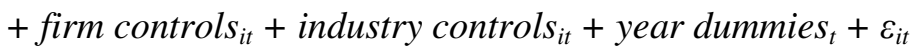

\section{Regression Results}

The correlation matrix for all of our independent variables is presented in Table 2 below. All of the correlation entries among different variables in this table are significantly below 0.9 , demonstrating that multicollinearity does not pose a serious problem to our analysis.

\section{[Insert Table 2 here]}

The panel data regression results for the formulation described in Equation (1) above are presented in Table 3, where each column represents a different performance measure regression. According to Table 3, we do not find evidence supporting Hypothesis 1 . None of the coefficients of the implementation variable is significantly different from zero. This may imply that potential negative impacts of BPR projects on firm performance variables during the implementation period are completely offset by their positive effects in the same period. Hypothesis 2 is uniformly supported as the coefficients of the post-implementation variable in Table 3 are significantly positive for all regressions. In other words, the firms in our sample have improved their performance in all three areas of interest after successfully implementing their BPR projects. Specifically, they have generated more sales and income per unit of input. In summary, we find a statistical association between improved firm 
performance and BPR projects during the post-implementation period without a significant drop in performance during the implementation period.

\section{[Insert Table 3 here]}

Recall that Hypothesis 3 is about the effect of project scope on firm performance. One would expect BPR-related benefits to increase with project scope, assuming that the risks of project implementation do not weigh in beyond a certain level of scope. The panel data regression results for the formulation described in Equation (2) are presented in Table 4.

\section{[Insert Table 4 here]}

Similar to the results regarding Hypothesis 1, we do not find a significant association between functionally focused or cross-functional BPR projects and firm performance during the implementation period, with the exception that functionally focused BPR implementation is (weakly) associated with higher return on equity during the same period ( $p$ value $<0.05$ ). On the other hand, we do observe a statistically significant (and positive) relationship between functionally focused BPR implementation and all measures of firm performance after the implementation period. Compared to firms that have not engaged in BPR, firms that implemented a narrowly focused project have generated more sales and income per unit of input after the implementation. Interestingly, we do not find a statistically significant association between cross-functional BPR projects and firm performance after the implementation period. In fact, the coefficient for the cross-functional post-implementation variable is smaller than that for the functional post-implementation variable for all estimations. This may imply that firms implementing BPR projects with a larger focus make a higher level of investment in organizational capital and assets, which may not lead to comparable increases in sales and income after the implementation period. Another 
implication of this finding is that the failure risk of BPR projects may increase beyond a certain level of scope, if not managed properly [52]. In a sense, this result is parallel to the observations reported in a relevant case study [38]. In fact, the existence of a high level of risk in large BPR projects may also explain the reason that many firms choose to implement only portions of enterprise-wide systems, such as Enterprise Resource Planning (ERP) [53, 54] that usually provides a means to do BPR [55].

The coefficients of our control variables in Tables 3 and 4 are in the expected direction. Firm size, IT budget, advertising expenditure, and market share are positively associated with all of our performance variables. Industry concentration is negatively associated with all of our performance variables. This implies that the average performance of a firm improves with the level of competitiveness in its industry, a finding that parallels those of Melville et al. [56]. Finally, we find a positive relationship between industry capital intensity and firm performance, which supports the view that incumbent firms in capital intensive industries could earn higher profits since they are likely to face fewer competitors [39].

\section{Conclusion}

This paper contributes to the growing literature on the business value of BPR projects. We empirically investigated the effects of BPR projects on firm performance both during and after the implementation periods by considering a variety of measures, including labor productivity, return on assets, and return on equity. We utilized panel data regression models, and explicitly considered the scope of BPR projects in our empirical analysis. We used a comprehensive data set spanning the period between 1984 and 2004. We found that while overall performance of firms remains unaffected during the implementation of the BPR 
projects, it increases significantly after the implementation period. We also found that functionally focused BPR projects on average are associated more positively with firm performance than those with a cross-functional scope. This may indicate that potential failure risk of BPR projects may increase beyond a certain level of scope.

There are certain limitations to this study. First, our results capture the effect of BPR initiatives averaged over a wide variety of firms and their projects. Although we report a significant association between improved firm performance and BPR implementation at the functional level, it is conceivable that some of these projects could have actually failed. Hence, our results can only represent an average performance measurement across multiple firms and projects. Second, our observations are unavoidably limited to those BPR projects that are publicly announced. Therefore, we may have missed some of the projects that have not been announced, and consequently miscoded some companies as non-implementers when, in fact, they have undertaken a BPR project. Finally, our empirical results need to be interpreted as correlations rather than estimates of a causal model.

There are interesting avenues for future research on this subject. Arguably, effectiveness of BPR projects may not be uniform across all activities of a firm. Therefore, our model can be extended to analyze the effects of BPR at the strategic business units of firms, rather than at the organizational level. This would be possible by defining new performance measures for different business units and comparing the resulting differences across them. Such an analysis may provide more specific insights about the design and value of BPR initiatives to project managers. 


\section{References}

1. Ozcelik Y. IT-enabled reengineering: Productivity impacts. Encyclopedia of Information Communication Technology 2008;2:498-502.

2. Caron JR, Jarvenpaa SL, Stoddard DB. Business reengineering at Cigna Corporation: Experiences and lessons learned from the first five years. MIS Quarterly 1994;18:233250.

3. Hammer M, Champy J. Reengineering the corporation: A Manifesto for business revolution. New York, NY: Harper Business Press; 1993.

4. Rock D, Yu D. Improving business process reengineering. AI Expert 1994;26(10):27-34.

5. Kleiner A. Revisiting reengineering. Strategy + Business 2000;20:27-31.

6. Grover V, Kettinger W. Process Think: Winning Perspectives for Business Change in the Information Age. Harrisburg, PA: Idea Group; 2000.

7. Barua A, Lee B, Whinston A. The calculus of reengineering. Information Systems Research 1996;7(4):409-428.

8. Martinez EV. Successful reengineering demands IS/business partnerships. Sloan Management Review 1995;36(4):51-60.

9. Davenport T, Short J. The new industrial engineering: Information technology and business process redesign. Sloan Management Review 1990;31(4):11-27.

10. Hammer M. Re-engineering work: Don't automate, obliterate. Harvard Business Review 1990;90(4):104-112.

11. Grover V, Malhotra M. Business process reengineering: A tutorial on the concept, evolution, method, technology and application. Journal of Operations Management $1997 ; 15: 193-213$.

12. Earl M, Khan B. How new is business process redesign? European Management Journal 1994;12(1):20-30. 
13. Deakins E, Makgill H. What killed BPR? Some evidence from the literature. Business Process Management Journal 1997;3(1):81-107.

14. Davenport T, Prusak L, Wilson H. What's the Big Idea? Creating and Capitalizing on the Best New Management Thinking. Boston, MA: Harvard Business School Press; 2003.

15. Hammer M. Process management and the future of Six Sigma. Sloan Management Review 2002;43(2):26-32.

16. Hammer M. Deep change: How operational innovation can transform your company. Harvard Business Review 2004;82(4):84-93.

17. Becker J, Kugeler M, Rosemann M. Process Management: A Guide for the Design of Business Processes. Berlin:Springer-Verlag; 2003.

18. El Sawy O. Redesigning Enterprise Processes for e-Business. Boston, MA: McGraw-Hill; 2001.

19. Kalakota R, Robinson M. Services Blueprint: Roadmap for Execution. Boston, MA: Addison-Wesley; 2003.

20. Silver E. Process management instead of operations management! Manufacturing \& Service Operations Management 2004;6(4):273-279.

21. Smith H, Fingar P. Business Process Management: The Third Wave. Tampa, FL: Meghan-Kiffer Press; 2003.

22. Brynjolfsson E, Hitt LM. Beyond computation: Information technology, organizational transformation and business performance. Journal of Economic Perspectives 2000;14(4): 23-48.

23. Sia SK, Neo BS. The impacts of business process re-engineering on organizational controls. International Journal of Project Management 1996;14(6):341-348. 
24. Hunter LW, Bernhardt A, Hughes KL, Skuratowicz E. It's not just the ATMs: Firm strategies, work restructuring and workers' earnings in retail banking. Working Paper, University of Pennsylvania; 2000.

25. Murnane RJ, Levy F, Autor D. Technological change, computers and skill demands: Evidence from the back office operations of a large bank. NBER Economic Research Labor Workshop; 1999.

26. Devaraj S, Kohli R. Information technology payoff in the health-care industry: A longitudinal study. Journal of Management Information Systems 2000;16(4):41-67.

27. Bresnahan TF, Brynjolfsson E, Hitt LM. Information technology, workplace reorganization, and the demand for skilled labor: Firm-level evidence. Quarterly Journal of Economics 2002;117(1):339-376.

28. Bertschek I, Kaiser U. Productivity effects of organizational change: Microeconometric evidence. Management Science 2004;50(3):394-404.

29. Al-Mashari M, Zairi M. BPR implementation process: An analysis of key success and failure factors. Business Process Management Journal 1999;5(1):87-112.

30. Guimaraes T. Field testing of the proposed predictors of BPR success in manufacturing firms. Journal of Manufacturing Systems 1999;18(1):53-65.

31. McKee D. An organizational learning approach to product innovation. Journal of Product Innovation Management 1992;9(3):232-245.

32. McPartlin JP. Seeing eye to eye on reengineering. Information Week 1992;15 June:74.

33. Grover V, Jeong SR, Kettinger WJ, Teng JTC. The implementation of business process reengineering. Journal of Management Information Systems 1995;12(1):109-144.

34. Ryan HW. Managing change. Information Systems Management 1992;9(3):60-62.

35. Cummings J. Reengineering is high on list, but little understood. Network World 1992;27 July:27. 
36. Grover V, Teng JTC, Fiedler KD. Information technology enabled business process redesign: An integrated planning framework. OMEGA 1993;21(4):433-447.

37. Berry D, Evans GN, Jones RM, Towill DR. The BPR scope concept in leveraging improved supply chain performance. Business Process Management Journal 1999;5(3): 254-275.

38. Dean AM. Managing change initiatives: JIT delivers but BPR fails. Knowledge and Process Management 2000;7(1):11-19.

39. Capon N, Farley JU, Hoenig S. Determinants of financial performance: A meta analysis. Management Science 1990;36(10):1143-1159.

40. Syzmanski DM, Bharadwaj SG, Varadarajan P. An analysis of the market shareprofitability relationship. Journal of Marketing 1993;57(3):1-18.

41. Megna P, Mueller DC. Profit rates and intangible capital. Review of Economics and Statistics 1991;73(4):632-642.

42. Nelson PB. Advertising as information. Journal of Political Economy 1974;82(4):729754.

43. Schmalensee R. A model of advertising and product quality. Journal of Political Economy 1978;86(3):485-503.

44. Buzzell RD, Gale BT. The PIMS principles: Linking strategy to performance. New York, NY: Free Press; 1987.

45. Day GS, Montgomery DB. Diagnosing the experience curve. Journal of Marketing $1983 ; 47(2): 44-58$.

46. Martin S. Market power and/or efficiency? Review of Economics and Statistics 1988;70(2):331-335.

47. Smirlock M, Gilligan T, Marshall W. Tobin's q and the structure-performance relationship. American Economic Review 1984;80(3):618-623. 
48. Jacobson R. Unobservable effects and business performance. Marketing Science 1990;9(1):74-85.

49. Jacobson R, Aaker DA. Is market share all that it's cracked up to be? Journal of Marketing 1985;49(4):11-22.

50. Porter M. Competitive strategy: Techniques for analyzing industries and competitors. New York, NY: Free Press; 1980.

51. Hitt LM, Wu DJ, Zhou X. Investment in enterprise resource planning: Business impact and productivity measures. Journal of Management Information Systems 2002;19(1):7198.

52. Remenyi D, Heafield A. Business process re-engineering: Some aspects of how to evaluate and manage the risk exposure. International Journal of Project Management 1996;14(6):349-357.

53. Markus ML, Grover V. Consolidating knowledge on the journey of business process transformation. Business Process Transformation - Advances in Management Information Systems 2008;9:1-19.

54. Markus ML, Tanis C, van Fenema PC. Multisite ERP implementations. Communications of the ACM 2000;43(3):42-46.

55. Wang P. Whatever happened to business process reengineering? Business Process Transformation - Advances in Management Information Systems 2008;9:23-40.

56. Melville N, Gurbaxani V, Kraemer K. The productivity impact of information technology across competitive regimes: The role of industry concentration and dynamism. Decision Support Systems 2007;43(1):229-242. 
Table 1. Construction of performance measures

\begin{tabular}{|l|c|c|}
\hline Performance Measure & Numerator & Denominator \\
\hline Labor Productivity & Sales & Number of Employees \\
\hline Return on Assets (ROA) & Income & Assets \\
\hline Return on Equity (ROE) & Income & Equity \\
\hline
\end{tabular}


Table 2. Correlation matrix for independent variables

\begin{tabular}{|c|c|c|c|c|c|c|c|c|}
\hline & Employees & Assets & Equity & IT budget & Advertising & $\begin{array}{l}\text { Market } \\
\text { share }\end{array}$ & $\begin{array}{c}\text { Industry } \\
\text { concentration }\end{array}$ & $\begin{array}{l}\text { Industry cap. } \\
\text { intensity }\end{array}$ \\
\hline Employees & 1.000 & & & & & & & \\
\hline Assets & $0.6040^{* * *}$ & 1.000 & & & & & & \\
\hline Equity & $0.6665^{\star \star \star}$ & $0.8950^{\star \star *}$ & 1.000 & & & & & \\
\hline IT budget & $0.7093^{* * *}$ & $0.8617^{* * *}$ & $0.8149^{* * *}$ & 1.000 & & & & \\
\hline Advertising & $0.7774^{\star \star \star}$ & $0.8463^{\star \star \star}$ & $0.8472^{* \star \star}$ & $0.8179^{* \star \star}$ & 1.000 & & & \\
\hline Market share & $0.2426^{* * *}$ & $0.2331^{* * *}$ & $0.2232 * * *$ & $0.2258 * * *$ & $0.2163^{* * *}$ & 1.000 & & \\
\hline $\begin{array}{l}\text { Industry } \\
\text { concentration }\end{array}$ & $-0.0649^{* * *}$ & $-0.2361^{* * *}$ & $-0.2288^{* * *}$ & -0.1860 *** & $-0.2244^{* * *}$ & $0.4561^{* * *}$ & 1.000 & \\
\hline $\begin{array}{l}\text { Industry cap. } \\
\text { intensity }\end{array}$ & -0.0264 ** & -0.0198 * & $0.0676^{* * *}$ & 0.0010 & $-0.0215^{* *}$ & -0.0062 & -0.0166 * & 1.000 \\
\hline
\end{tabular}


Table 3. Regression results for during and post-BPR implementation

\begin{tabular}{|l|c|c|c|}
\hline Dependent Variable & log (sales) & $\log$ (income) & log (income) \\
\hline Interpretation & Labor productivity & Return on assets (ROA) & Return on equity (ROE) \\
\hline During implementation & -0.00028 & -0.00105 & 0.00288 \\
\hline Post-implementation & $0.00433^{* *}$ & $0.01038^{* *}$ & $0.01335^{* * *}$ \\
\hline log (employees) & $0.43507^{* * *}$ & $0.15258^{* * *}$ & $0.11808^{* * *}$ \\
\hline log (assets) & & $0.57193^{* * *}$ & \\
\hline log (equity) & & & $0.59733^{* * *}$ \\
\hline log (IT budget) & $0.17298^{* * *}$ & $0.04928^{* * *}$ & $0.05271^{* * *}$ \\
\hline log (advertising) & $0.07544^{* * *}$ & $0.04186^{* * *}$ & $0.02936^{* * *}$ \\
\hline Market share & $1.90082^{* * *}$ & $0.09088^{* *}$ & 0.21720 \\
\hline Industry concentration & $-0.07500^{* *}$ & $-0.22265^{* *}$ & $-0.20055^{* *}$ \\
\hline Industry capital intensity & $0.27603^{* *}$ & $0.77605^{* *}$ & $0.44557^{*}$ \\
\hline$R^{2}$ & $0.8091^{* *}$ & $0.7044^{*}$ & $0.7545^{* *}$ \\
\hline Note: ${ }^{* * *} p<0.001 ;{ }^{* *} p<0.01 ;{ }^{*} p<0.05$. & & \\
\hline
\end{tabular}


Table 4. Regression results for the effect of project scope

\begin{tabular}{|c|c|c|c|}
\hline Dependent Variable & $\log$ (sales) & $\log$ (income) & $\log$ (income) \\
\hline Interpretation & Labor productivity & Return on assets (ROA) & Return on equity (ROE) \\
\hline Functional during implementation & 0.00225 & 0.01600 & 0.01833 * \\
\hline Functional post-implementation & $0.00596^{* *}$ & $0.02049^{* * *}$ & $0.02209 * * *$ \\
\hline Cross-functional during implementation & -0.00173 & -0.01058 & -0.00588 \\
\hline Cross-functional post-implementation & 0.00325 & 0.00399 & 0.00783 \\
\hline $\log$ (employees) & $0.43500^{* * *}$ & $0.15223^{* \star *}$ & $0.11758^{* * *}$ \\
\hline $\log$ (assets) & & $0.57113^{* * *}$ & \\
\hline $\log$ (equity) & & & 0.59664 *** \\
\hline $\log$ (IT budget) & $0.17287^{* * *}$ & $0.04881^{* * *}$ & 0.05236 *** \\
\hline log (advertising) & $0.07545^{* * *}$ & $0.04208^{* * *}$ & $0.02957^{* * *}$ \\
\hline Market share & 1.89565 *** & 0.05797 & 0.18845 \\
\hline Industry concentration & $-0.07531^{* *}$ & -0.22466 ** & $-0.20338^{* *}$ \\
\hline Industry capital intensity & $0.27894^{* *}$ & $0.79223^{* *}$ & 0.45955 \\
\hline$R^{2}$ & 0.8091 & 0.7047 & 0.7548 \\
\hline
\end{tabular}

